\title{
HT29 Hücre Hattında Sirkadiyen Ritme Bağlı Gen İfadesinin Kontrolünde Referans Gen Farklılığının Senkronizasyondaki Rolü
} Beyza GÖNCÜ*1®, Dilek ÖZTÜRK ${ }^{2}$ (D)

\author{
${ }^{1}$ Bezmialem Vakıf Üniversitesi, Deneysel Uygulama ve Araştırma Merkezi \\ ${ }^{2}$ Bezmialem Vakıf Üniversitesi, Eczacılık Fakültesi, Farmakoloji Anabilim Dalı
}

Geliş / Received: 06.02.2019, Kabul / Accepted: 09.10.2019

\section{$\ddot{O} \mathbf{z}$}

Sirkadiyen zamanlama sistemi, memeli organ ve hücrelerinde bulunan moleküler saatler aracılığı ile pek çok hayati fonksiyonu kontrol etmektedir. Son yıllarda yapılan çalışmalar ile sirkadiyen ritmin hastalıklardaki rolü daha iyi anlaşılmıştır. Bu kapsamda gerçekleştirilecek hücre kültürü çalışmalarında öncelikli olarak senkronizasyonun sağlanması ve kontrolü önem arz etmektedir. Sunduğumuz çalışmada besin aracılığı ile senkronize edilen HT-29 hücrelerinde, senkronizasyon saat geni olarak da bilinen PER2 ve iki farklı referans gen ile kontrol edilmiştir. Amacımız senkronizasyon kontrolünde referans genlerin rolünü incelemektir. $\mathrm{Bu}$ amaçla; serum şokunu takiben HT-29 hücreleri T0 zamanından itibaren 6 farklı zamanda toplanarak RNA izole edilmiş ve PER2, ACTB ve RPLPO gen ekspresyonları gerçek zamanlı PZR (RT-PZR) deneyi ile kantifiye edilmiştir. Sonuçlar Fourier transformasyon ve Lineer Cosinor analizleri ile değerlendirilmiştir. $A C T B$ referans geni seçildiğinde Fourier transformasyon analizi ile 24 ve 30 saatlik periyotlar anlamlı değişim gösterirken, Lineer Cosinor analizi ile sadece 24 saatlik periyot süresi anlamlı değişim göstermiştir. RPLPO referans geni seçildiğinde her iki analiz ile de 18 saatlik periyot süresi anlamlılık göstermiştir. Bulguların gösterdiği gibi senkronizasyonun başlatılması ve kontrolünde referans gen ve analiz yöntemi gibi pek çok parametrenin birlikte değerlendirilmesi önem arz etmektedir. Yapılan çalışmanın bu alanda yapılacak in vitro çalışmalar için farkındalık yaratacağı düşünülmektedir.

Anahtar Kelimeler: senkronizasyon, sirkadiyen ritim, HT29, PER2

\section{The Role of Reference Gene Differences in Synchronization Control of Circadian Rhythm-Induced Gene Expression in the HT29 Cell Line}

\begin{abstract}
Circadian timing system controls many important vital functions through molecular clocks in mammalian organs and cells. The role of circadian rhythm in diseases has been better understood in recent years. In cell culture studies to be carried out in this area, primarily important things are ensuring synchronization and its control. In this study, the synchronization was controlled by PER2 clock gene and the two reference genes in nutrient-mediated synchronized HT-29 cells. Our aim is to investigate the role of reference genes in synchronization control. For this purpose, following serum shock HT-29 cells were harvested at 6 different times, RNA isolation was made and PER2, ACTB, and RPLPO gene expressions were quantified by real-time PCR (RT-PCR) assay. The results were evaluated with Fourier transformation and Linear Cosinor analysis. When the $A C T B$ reference gene was selected, 24 and 30 hour periods showed a significant change by Fourier analysis and 24-hour period showed a significant change with Cosinor analysis. When the RPLPO reference gene was selected, the 18 hour cycle time was significant with both analyzes. As the findings show, it is important to evaluate several parameters such as reference gene and analysis method in the initiation and control of synchronization. It is thought that this study will create awareness for in vitro studies in this area.
\end{abstract}

Keywords: Synchronization, circadian rhythm, HT29, PER2 


\section{Giriş}

Doku büyümesi, kan basıncinın kontrolü, kalp atımı ve kan şekerinin düzenlenmesi gibi metabolik süreçler sirkadiyen ritim olarak adlandırılan biyolojik bir saat ile düzenlenmektedir. Memeli sirkadiyen sistemi, hipotalamusta bulunan ve merkezi osilatör olan Suprakiazmatik Çekirdek (SCN) aracılığıyla düzenlenir. Gün 1şığına bağlı olarak SCN'de oluşan ritim, pek çok nöronal ve hormonal ritim aracıllğ 1 ile tüm hücrelerde bulunan periferal saatlerin senkronize olmasını sağlar. Periferik dokuların senkronizasyonu ise periferal saatler ile ilişkilidir. Aynı zamanda, SCN aracılı hormonların salınımları ile ilişkili olabildiği gibi besin alımı ve fiziksel aktivite gibi çevresel faktörlere de bağlıdır (Momma et al., 2017; Pardini, Kaeffer, Trubuil, Bourreille, \& Galmiche, 2005; Reszka \& Zienolddiny, 2018).

Senkronizasyon; bir diğer deyişle intrasellüler osilatör ritmin düzenlenmesi, farklı genler aracılığıla meydana gelmektedir. Bugüne kadar bu genlerden 20'ye yakını tanımlanmıştır (Schibler et al., 2015). Senkronizasyonla ilişkili genler "saat genleri” olarak adlandırılır (Özbayer, 2011) ve komplike bir ağ aracillğıyla birbirinden bağımsız ve kendi kendine hareket eden, transkripsiyonel ve translasyonel geri bildirim döngüsüyle ritmi meydana getirirler (Reszka \& Zienolddiny, 2018). Bu sistemin kontrolü üç ayrı otoregülatör: transkripsiyonel-translasyonel, pozitif ve negatif düzenleyici (trans- ve cis- elementleri dahil) elementler ile sağlanır.

Saat genlerinden Periyot 2 (PER2), birçok memeli dokularında eksprese olarak yüksek amplitüt oluşturup ritim senkronizasyonunda görev alır. Birçok in vitro çalışmada, malign hücrelerde PER2 ekspresyon artışının artan apoptoz ve azalan hücre proliferasyonu ile ilişkili olduğu gösterilmiştir (Mteyrek, Filipski, Guettier, Okyar, \& Levi, 2016).

Literatürde in vitro çalışmalarda hücre hatlarında sirkadiyen ritmin sekronizasyonunun başlatılması için farklı indükleyiciler kullanılmıştır. Bunlar; \% 50 at/bovin serum (FBS) içeren medyum, dekzametazon (Dex) (glukokortikoid reseptör agonisti), forskolin (Fsk), epidermal büyüme faktörü (EGF), iyonomisin, 8-bromo-cAMP, fibroblast büyüme faktörü (bFGF), ET-1 (mitojen aktivasyon yolağında protein kinaz aktivatörü bir protein kinaz $\mathrm{C}$ ), ve prostaglandin E'dir (PGE) (Izumo, Sato, Straume, \& Johnson, 2006).

$\mathrm{Bu}$ çalışmada amacımız, HT29 (insan epitelyal kolorektal adenokarsinom) hücre hattında besin aracılı senkronizasyonun başlatılmasında iki farklı referans genin etkisinin incelenmesidir. Çalışmada, model olarak HT29 kolon kanser hücreleri seçilmiştir. Bunun nedeni kolon kanserinin dünyadaki en ölümcül üçüncü kanser tipi olmasıdır (Siegel et al., 2017). Besin aracilı (\%50 FBS içeren kültür medyumu) senkronizasyonun başlatılmasını takiben, sirkadiyen ritme bağl1 genlerden PER2 gen ekspresyonu, iki farklı referans gen olan $\beta$ aktin (ACTB), RPLPO kullanılarak değerlendirilmiştir.

\section{Materyal ve Metot}

Hücre Kültürü: Çalışmada, HT29 hücre hattı kullanıldı ve çalışmanın tamamı pasaj 17-25'e kadar olan sürede gerçekleştirildi. HT29 hücreleri için DMEM/F12 medyum (Gibco, ThermoFisher, Waltham, MA, USA) ve $\% 10$ FBS (Panbiotech, Aidenbach, Germany), \%1 penisilin/streptomisin (Panbiotech, Aidenbach, Germany) ile 
beraber kullanıld1. Hücreler $37^{\circ} \mathrm{C}^{\prime}$ de $\% 5 \mathrm{CO}_{2}$ içeren hücre kültür inkübatörü kullanılarak, her 2-3 günde bir $\% 80$ konflüent olduklarında pasajlandı. Her pasaj esnasında $\% 0,05$ tripsin-EDTA (Panbiotech, Aidenbach, Germany) kullanıldı.

Senkronizasyon: HT29 hücreleri 6-kuyulu plakalara \%15-20 konflüent olacak şekilde kültüre edildi. Kültürün başlamasından 12 saat sonra 6-kuyulu plakalar iki ayrı grup olacak şekilde ayrıldı ve medyumları uzaklaştırıldı. Hücrelere \%50 FBS içeren kültür medyumu eklendi. İki saat süre ile FBS aracılı senkronizasyon şoku daha önce bildirildiği gibi uygulandı (Balsalobre, Damiola, \& Schibler, 1998; Izumo et al., 2006). Senkronizasyon şok süresi tamamlandıktan sonra hücreler normal kültür medyum koşullarına alındı. Belirlenen zaman aralıklarında, ileri aşamalar için kültürden hücreler toplandi. HT29 hücreleri için belirlenen zaman aralıkları sırasıyla; serum şok sonlandırıldığ 1 an zaman dilimi sıfır olarak kabul edildi (T0), serum şok tamamlanmasinı takiben 6. saat ' $T 6$ ', 12. saat 'T12', 18. saat 'T18', 24. saat 'T24', ve 30. saat 'T30' olarak kabul edildi. Tüm zaman aralıkları triplike olarak çalışıldı.

RNA izolasyonu: Gen ekspresyon analizleri için High Pure RNA Isolation Kit (Roche, Mannheim, Germany) kullanılarak total RNA'lar izole edildi. Deney düzeneğindeki kültürden elde edilen her hücre grubu tripsinize edilerek toplandı. 320 g'de 5 dakika santrifüj edildi. Süpernatant kısmı atıld1 ve hücre pelleti $200 \mu l \quad 1 X$ PBS içerisinde süspanse edildi. Hücrelerin üzerine $400 \mu \mathrm{l}$ lizis tamponu eklendi. Karışım 15 saniye vorteks yardımıyla homojenize edildikten sonra cam lifli, filtreli tüplere aktarıldı. 8000 g'de $+4^{\circ} \mathrm{C}$ 'de 15 saniye santrifüj edildi. Filtrenin altına geçen süpernatant atıldı. $90 \mu$ Dnase inkübasyon tamponu ve $10 \mu \mathrm{l}$ DNAse I'den oluşan karışım hazırlandı. Tamamı filtreli tüpe aktarılarak 15 dakika oda sıcaklığında inkübe edildi. İnkübasyonu tamamlanmış örneklerin üzerine $500 \mu \mathrm{l}$ yıkama tamponu I eklenip, 8000 g'de $+4^{\circ} \mathrm{C}$ 'de 15 saniye santrifüj edildi ve süpernatant uzaklaştırıldı. Devamında 500 4 l yıkama tamponu II eklenip, 8000 g'de $+4^{\circ} \mathrm{C}$ 'de 15 saniye santrifüj edildi ve üçüncü yıkama işlemi için yeniden $200 \mu \mathrm{l}$ yıkama tamponu II eklenerek 12000 g'de $+4^{\circ} \mathrm{C}^{\prime}$ de 2 dakika santrifüj edildi. Filtreli kısım yeni bir tüpe aktarıldı. Son olarak 50-70 $\mu$ l elüsyon tamponu eklenerek, 8000 g'de $+4^{\circ} \mathrm{C}^{\prime}$ de 1 dakika santrifüj edilerek total RNA elüsyonu tamamlandı. Elde edilen RNA'nın miktarı ve saflığı ve miktarı NanoDrop (ThermoFisher, Waltham, MA, USA) cihaziyla spektrofotometrik olarak belirlendi.

cDNA Sentezi: İzole edilen total RNA'lardaki mRNA'ların RT-PZR (Revers Transkriptaz - Polimeraz Zincir Reaksiyonu) ile komplementer DNA'larının (cDNA) oluşturulması için uygun kit kullanılarak thermal cycler cihazı ile PZR'lar1 gerçekleştirildi. $\mathrm{Bu}$ amaçla High-Capacity cDNA Reverse Transcription Kit kullanıdı. cDNA sentezi için $10 \mu$ lotal RNA kullanılarak cDNA reaksiyonu tamamlandı.

RT-PZR: Elde edilen cDNA'lardan hedef gen olan PER2 mRNA seviyesindeki değişim oranları iki ayrı referans gen olan $A C T B$ ve RPLPO ekpresyonu ile kiyaslanması sonrasında saptandı. Özgül olarak dizayn edilen primerler; PER2: ileri AAATCCGCTACCACCCCTTC, geri AAGGCAGCAAAGCTGACTCTC, ACTB: ileri CATGTACGTTGCTATCCAGGC, geri CTCCTTAATGTCACGCACGAT ve RPLPO: ileri AGCCCAGAACACTGGTCTC, geri ACTCAGGATTTCAATGGTGCC. Tasarlanan 
primerlerin erime sicaklığ 1 (Tm) $62,6^{\circ} \mathrm{C}$ olarak belirlenmiştir. RT-PZR işleminde; her bir örnek için $6 \mu 1$ distile su, $1 \mu 1$ ileri primer, $1 \mu 1$ geri primer, $10 \mu 1$ SensiFAST SYBR Mix (Bioline, Luckenwalde, Germany) eklenerek mikrosantrifüj tüpüne konuldu. Hazırlanan PZR karışımı homojen hale getirilmesi için kısa süreli vortekslendi. PZR karışımı, her bir örnek için lightcycler kapiller tüplere $18 \mu \mathrm{l}$ olacak şekilde aktarıldı ve $2 \mu \mathrm{l}$ cDNA örnekleri eklendi.

Termal döngü, $95^{\circ} \mathrm{C}$ 'de 2 dakika 1 siklus ön denatürasyonun ardından toplam 40 siklusluk $95^{\circ} \mathrm{C} 5$ saniye denatürasyon, $62,6^{\circ} \mathrm{C}$ 'de $(\mathrm{Tm})$ 10 saniye bağlanma ve $72^{\circ} \mathrm{C}^{\prime}$ de 20 saniye sentez ile tamamland. SYBR Green hidrolizine bağlı floresan artışı görülen inceleme örneklerinden elde edilen grafiklerdeki cycle of threshold $(\mathrm{Ct})$ verileri değerlendirildi. mRNA ekspresyon değerlerinin belirlenmesi için yapılan gerçek zamanlı PZR (RT-PZR) deneylerinde kullanılan örnekler ikili olarak çalışıldı. Elde edilen $\mathrm{Ct}$ değerlerinin ortalaması alındı. Genlerin değişim oranları $2^{-\Delta \Delta \mathrm{Ct}}$ (hedef gen referans gen) yöntemi kullanılarak hesaplandı.

İstatistiksel Analiz: Ritme bağlı zaman aralıklarına ait one-way ANOVA analizi Prism 7.0 programı (GraphPad Software, Inc., CA, USA) kullanılarak yapıldı. Ritme bağlı değişimin sinüzoidal fonksiyonunun bir sirkadiyen ritmindeki anlamlılığ algoritmas1 (Cornelissen, 2014; Fourier, 1822; Nelson, Tong, Lee, \& Halberg, 1979) kullanılarak Fourier transformasyon (SPSS, IBM Corp.) analizi ve Lineer Cosinor
(MathLab, The MathWorks Inc., Massachusetts, USA) ile hesapland1. Anlamlı bulunan "Bir Periyot" süresine ait güven aralığının zaman diliminde gösterimi MathLab programı (The MathWorks Inc., Massachusetts, USA) kullanılarak çizildi. $\mathrm{P} \leq 0,05$ olan değerler istatistiki olarak anlamlı kabul edildi.

\section{Bulgular}

FBS aracılı senkronizasyon şokun tamamlanması ile belirlenen zaman aralıklarında (6 saatte bir); T0, T6, T12, T18, T24, T30 sürelerinde, HT29 hücreleri kültürden toplanarak PER2 genine ait mRNA ekspresyonlarındaki değişim belirlendi ve $A C T B$ ile RPLPO ekspresyon değerleriyle kıyaslanarak değerlendirildi (Şekil 1).

One-way ANOVA testi zaman aralıklarındaki mRNA ekspresyonlarının, birbirleri arasındaki anlamlı değişiminin belirlenmesi için kullanılmıştır. mRNA rölatif gen ekspresyon değişimleri; T0, T18 ve T30 zaman aralıkları için anlamlı farklılık göstermemiştir. Ancak T6, T12, T24 zaman aralıklarında PER2/ACTB oranı $P E R 2 / R P L P 0^{\prime}$ a göre anlamls şekilde az bulunmuştur (sırasılyla $\mathrm{p}=0,0163$ (T6), $\mathrm{p}=0,0026$ (T12), $\mathrm{p}<0,0001$ (T24)). Çalışmada zaman serisine bağlı değişimin anlamlılı̆̆ Fourier transformasyon analizi ile yapild. Ek olarak, HT29 hücreleri için 30 saat bir periyot süresi olarak (Bairoch, 2018) kabul edildi. Fakat yapılan tüm analizlerde ilave olarak 18., 24. ve 30. saatlerdeki veriler, her analizin tekrarı için "Bir Periyot" süresi olarak kabul edilerek tamamlandi. 


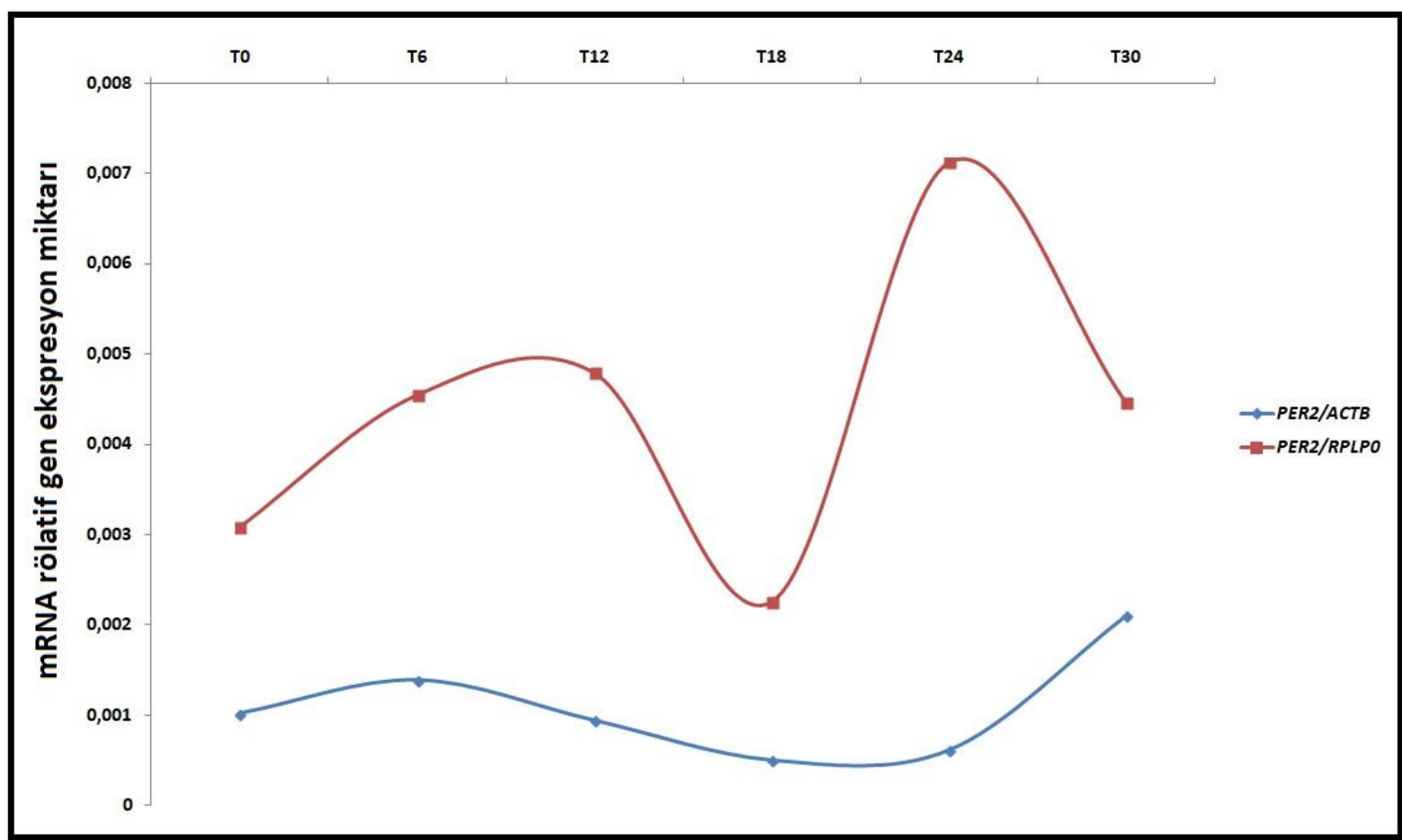

Şekil 1: PER2 mRNA rölatif gen ekspresyonunun $A C T B$ ve $R P L P O$ referans genlerine bağl1 senkronizasyon şoku sonrası belirlenen zaman aralıklarına göre değişimi.

Tablo 1'de PER2/ACTB ve PER2/RPLPO'a hesaplamalarda kullan1lan "Bir Periyot" göre Fourier transformasyon analizinde elde süresince değişimi gösterilmektedir. edilen akrofaz, amplitüt ve p değerlerinin,

Tablo 1: PER2 mRNA ekpresyonunun $A C T B$ ve RPLPO referans genleri ile farkl1 "Periot" sürelerine bağlı olarak yapılan Fourier transformasyon analiz sonuçları.

\begin{tabular}{ccccc}
\hline & $\begin{array}{c}\text { Period Süresi } \\
\text { (saat) }\end{array}$ & Akrofaz & Amplitüt & p değeri \\
\hline \multirow{2}{*}{ PER2/ACTB } & 18 & 11,10262 & 0,00044 & 0,1779 \\
& 24 & 6,593487 & 0,00066 & $\mathbf{0 , 0 1 2 7}$ \\
& 30 & 3,503404 & 0,00059 & $\mathbf{0 , 0 3 5 8}$ \\
\hline \multirow{2}{*}{ ER2/RPLPO } & 18 & 7,890150 & 0,001846 & $\mathbf{0 , 0 1 6 6}$ \\
& 24 & 4,285075 & 0,000958 & 0,4458 \\
& 30 & 25,82534 & 0,000502 & 0,8003 \\
\hline
\end{tabular}

Referans gen olarak yalnızca $A C T B$ verileri $\mathrm{p}=0,0166)$. $P E R 2$ mRNA ekpresyonunun değerlendirildiğinde sirkadiyen ritim sırasıyla $A C T B$ ve $R P L P O$ referans genleri ile farklı 24. ve 30. saatte "Bir Periyot" olarak "Periyot" sürelerine bağlı olarak yapılan tamamlanmaktadır (T24 p=0,0127, T30 Lineer Cosinor analiz sonuçları ise Tablo $\mathrm{p}=0,0358)$. Referans gen olarak yalnızca 2'de gösterilmektedir. Lineer Cosinor $R P L P O$ verileri değerlendirildiğinde ise hesaplamalarında referans gen $A C T B$ sirkadiyen ritim yalnızca 18 saatte bir "Bir verilerine göre "Bir Periyot" 18 saat kabul Periyot" olarak tamamlanmaktadır (T18 edildiğinde PER2/ACTB güven aralığ1, 
zaman dilimi sınırlarının dışında kalmış ve akrofaz, amplitüt değerleri hesaplanamamıştır. Güven aralığı sınırlarında kalan ve referans gen olarak; $A C T B$ verileri değerlendirildiğinde sirkadiyen ritim 24 . saatte $(\mathrm{p}=0,0005)$ ve $R P L P O$ verileri değerlendirildiğinde ise 18 . saatte $(p<0,0001)$ "Bir Periyot" süresini tamamladığ 1 belirlenmiştir.

Tablo 2: PER2 mRNA ekpresyonunun $A C T B$ ve RPLPO referans genleri ile farkl1 "Periot" sürelerine bağlı olarak yapılan Lineer Cosinor analiz sonuçları.

\begin{tabular}{lcccc}
\hline & $\begin{array}{c}\text { Period Süresi } \\
\text { (saat) }\end{array}$ & Akrofaz & Amplitüt & p değeri \\
\hline \multirow{2}{*}{ PER2/ACTB } & 18 & - & - & - \\
& 24 & 0,00047 & 4,8617 & $\mathbf{0 , 0 0 0 5}$ \\
& 30 & 0,00132 & 4,4615 & 0,2681 \\
\hline \multirow{PER}{*}{$/ \boldsymbol{R P L P O}$} & 18 & 0,00148 & 4,5013 & $<\mathbf{0 , 0 0 0 1}$ \\
& 24 & 0,00066 & 5,7821 & 0,8528 \\
& 30 & 0,00327 & 4,6252 & 0,1916 \\
\hline
\end{tabular}

PER2 mRNA ekspresyonunun referans genler ile gösterilen rölatif mRNA ekspresyonunun; Fourier transformasyon ve Lineer Cosinor analiz sonuçlarıyla anlamlı bulunan referans gen $A C T B$ için T24 ve RPLPO için T18 "Bir Periyot" ritmine ait, güven aralığının zaman diliminde gösterimi ise Şekil 2'de verilmiştir.

\section{Sonuç}

\section{Sonuç ve Tartışma}

Memeli doku ve organlarında her hücrenin belirli bir oranda ritmik gen ekspresyonuna sahip olduğu bilinmektedir Sirkadiyen zamanlama sistemi bu ritmik ekspresyonlar $\operatorname{arac}_{1 l} \breve{g ̆}_{1}$ ile uyku-uyanıklık, aktivitedinlenme, vücut sıcaklığı, besin alımı, hormon salınımı, hücre siklusu, DNA onarımı ve apoptoz gibi fizyolojik ve biyokimyasal süreçleri etkilemektedir ve bu nedenle sirkadiyen ritmin senkronizasyonu tüm hücreler için hayati önem arz etmektedir (Levi, Okyar, Dulong, Innominato, \& Clairambault, 2010; Schibler, 2005).
Senkronizasyonda görevli oto-regülatör elementler sirasıyla; Morning-Time (E-box), Day-Time (D-box) ve Night-Time ROR elements (RRE) olarak bilinir (Minami, Ode, \& Ueda, 2013; Zhang, Dong, Fujimoto, \& Okamura, 2004). CLOCK ve BMAL genleri (E-box transkripsiyon faktörleri-aktivatörleri) ve bu genlerin hedefi olan Periyot (PER 1, 2, 3), Kriptokrom ( $C R Y$ 1, 2) genleri (E-box transkripsiyon faktörleri-inhibitörleri) ile "Saat" kontrol altındadır.

$P E R$ genlerinin ürünleri olan proteinler $B M A L$ genlerinin transkripsiyonlarını ilerletmek için pozitif etki oluştururlar. $B M A L$ ile $C L O C K$ genlerinin heterodimerizasyonu ile senkronizasyon yeniden başlar (Reszka \& Zienolddiny, 2018). Epidemiyolojik çalışmalar, sirkadiyen ritme ait düzenin bozulmasının prostat, meme, endometriyal ve kolorektal kanser tiplerinin gelişme riskini artırdığını göstermiştir (Reszka \& Zienolddiny, 2018). 

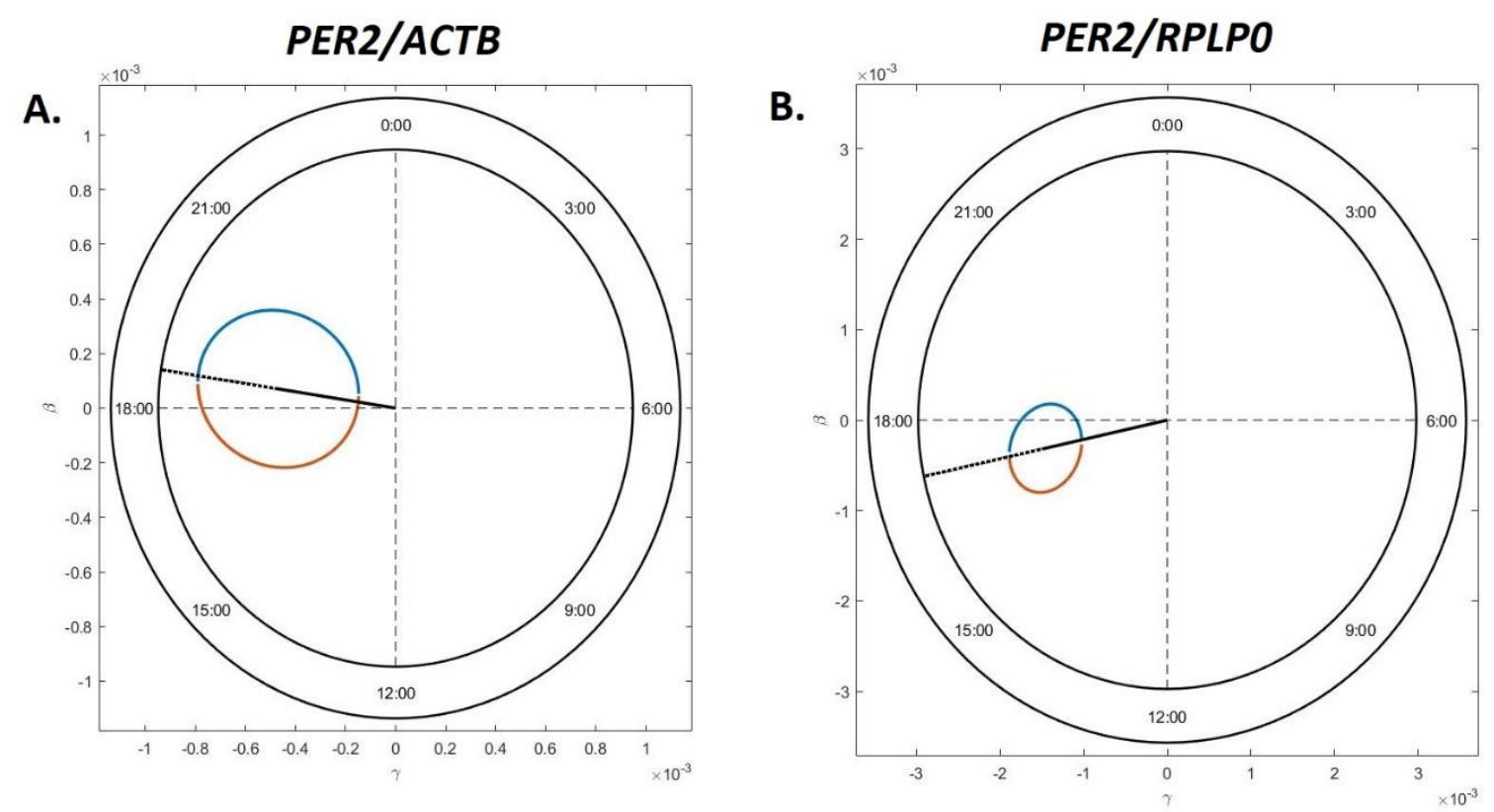

Şekil 2: "Bir Periyot" süresine ait güven aralığının zaman diliminde gösterimi. A.PER2 mRNA ekspresyonunun $A C T B$ referans genine bağlı olarak anlamlılığı belirlenen 24 saatte tamamlanan "Bir Periyot" süresinin güven aralığının zaman diliminde gösterimi. B. PER2 mRNA ekspresyonunun $R P L P O$ referans genine bağlı olarak anlamlılığ belirlenen 18 saatte tamamlanan "Bir Periyot" süresinin güven aralığının zaman diliminde gösterimi. Zaman dilimindeki daire çapı, güven aralılığının anlamlılığı arttıkça küçülmektedir.

Kronik miyeloid lösemi (Yang et al., 2011), akut miyeloid lösemi (Puram et al., 2016), ailesel ve sporadik meme kanseri (Lesicka et al., 2018; Winter, Bosnoyan-Collins, Pinnaduwage, \& Andrulis, 2007) ve kolon kanseri (Mazzoccoli, Vinciguerra, Papa, \& Piepoli, 2014) gibi hastalıklarda sirkadiyen ritmin sekronizasyonunun bozulduğu gösterilmiştir. Kolon kanserinin etiyolojisi, aşırı alkol tüketimi, sigara, düşük fiziksel aktivite, vücut kitle indeksindeki artış gibi birçok risk faktörü içermektedir; mortalite oranı yılda 700.000 kişidir (Brody, 2015). Türkiye'de ise bu oran her yüz bin kişi de 23,4'dür ("Türkiye Kanser İstatistikleri," 2015). Kolon kanseri üzerine son y1llarda yapılan çalışmalarla terapötik yaklaşımlar önem kazanmıştır (Dallmann, Okyar, \& Levi, 2016; Ozturk, Ozturk, Kavakli, \& Okyar, 2017). Bu kapsamda kemoterapi uygulamasının sirkadiyen ritme bağlı olarak günün farklı zamanlarında uygulanması ile yapılan kronoterapi çalışmaları hız kazanmıştır (Pilanci et al., 2016).

Yapılan çalışmalarla "Saat Genleri"ne ait senkronizasyonun dokulara spesifik bir şekilde düzenlendiği gösterilmiştir. Literatürde, hem mRNA ekspresyon değişimlerinin hem de iki ayrı osilatör mekanizmanın bu ekspresyon değişimindeki etkinliğinin ( $\mathrm{SCN}$ ve Periferal Sistem) dokular arasındaki farklılığı bildirilmiştir (Akashi \& Takumi, 2005; Sato et al., 2004). Ayrıca, deney hayvanları ile gerçekleştirilen in vivo bir çalışmada CLOCK-deficient olan fare karaciğerinde Periyot mRNA ritminin stabil olduğu fakat SCN' deki ekspresyonunun kaybolduğu gösterilmiştir (Debruyne et al., 2006). Başka bir çalışmada, PER1 ve PER2 genlerinin beta-katenin yolağını ve hücre proliferasyonunu düzenlediği ve özellikle, kolon kanseri tümörleri ve diğer tümörlerin bir kısmında, 
Periyot genlerinde mutasyon olduğu bildirilmiştir (Wood, Yang, \& Hrushesky, 2009). PER2 geninin sirkadiyen düzendeki etkinliği sayesinde malign transformasyonu baskıladığı Katamune ve arkadaşlarının yaptığ1 çalışma ile gösterilmiştir. $\mathrm{Bu}$ çalışmada, PER2-mutant embriyonik fibroblast hücrelerinde hem spontan hem de radyasyonla indüklenen tümör gelişimi ve rutin kemoterapötik ilaçlara da direnç geliştiği in vivo olarak gösterilmiştir (Katamune et al., 2018).

Bilindiği üzere sirkadiyen ritim hesaplamaları için matematiksel modellemeler kullanılmaktadır. Bunlar arasında; Fourier Transformasyon Analizi, Rayleigh Testi, Enright Periyotogram, Lomb - Scargle Periyotogram ve Lineer Cosinor testleri bulunmaktadir (Refinetti, Lissen, \& Halberg, 2007). Fourier transformasyon analizi Joseph Fourier tarafindan 1822'de gösterilmiştir (Fourier, 1822). Herhangi bir zaman serisinde, şekle veya düzenliliğe (regularity) bağlı olmaksızın, bir seride yer alan çeşitli frekanslardaki sinüs ve kosinüs dalgası olarak tanımlanmaktadır (Refinetti et al., 2007). Ayrica tahmin edilen bir ritim zamanında, "bir Periyot"un kosinüs fonksiyonunun belirlenmesi için Lineer Cosinor kullanılmaktadır. Güven aralığına bağlı olarak optimum interpolasyonu tahmin etmeye yarayan, lineer olan ve olmayan Cosinor yöntemi 1963'de Marquardt tarafindan gösterilmiştir (Marquardt, 1963).

Çalışmada, ritme bağlı değişimin anlamlılığ Fourier transformasyon ve Lineer Cosinor analizi ile değerlendirilmiştir. Hesaplamaların yapılabilmesi için ritmin senkronizasyonu 18,24 ve 30 saatte tamamlandığ 1 tahmin edilmiştir. Analizler sonucunda referans gen farklılığı net bir şekilde PER2 mRNA ekspresyonuna bağlı olarak "Bir Periyot" süresinin değişkenliğini ortaya koymuştur. Fourier transformasyon analizinde $A C T B$ referans geni seçildiğinde "Bir Periyot" 24. veya 30. saatler seçilerek anlamlı kabul edilebilirken, RPLPO açısından yalnızca 18 saat anlamlı bulunmuştur. Diğer yandan Lineer Cosinor analizi'ne göre $A C T B$ referans geni için yalnızca 24. saat ve RPLPO referans geni açısından 18. saat "Bir Periyot" süresini tamamladığı gösterilmiştir. Ek olarak, HT29 hücrelerinde senkronizasyonun başlatılması için kullanılan FBS'nin kimyasal bir aracı gerektirmeden sirkadiyen ritmin indüksiyonu için yeterli olduğu gözlenmiştir.

Sonuç olarak, PER2 genine ait mRNA ekspresyonundaki değişim iki ayrı matematiksel hesaplama ile anlamlı bulunan ve iki ayrı referans gen olan $A C T B$ ve $R P L P O$ ile değerlendirildiğinde HT29 hücrelerinin sirasiyla 24 ve 18 saatte bir senkronizasyonu ("Bir Periyot") gerçekleştirdiği gösterilmiştir. $\mathrm{Bu}$ veriler; matematiksel modellemelerin ve referans genlere bağlı olarak "Bir Periyot" süresinin değişiminin, ilerleyen çalışmalar için daha belirleyici parametrelerin gerektiğine işaret etmektedir. Referans gen'e bağlı olarak ritim süresindeki anlamlılığın diğer "Saat Genleri" ile beraber değerlendirmenin gerekliliği unutulmamalidir.

\section{Öneriler}

In vitro çalışmaların tek tip hücre hatlarında gerçekleştirilmesi, genlerin fonksiyonel durumlarının belirlenmesi için uygulamada kolaylık sağlamaktadır ancak, sirkadiyen ritmin iki osilatör mekanizmadaki etkilerinin iyi anlaşılması ve terapötik yaklaşımların geliştirilebilmesi için in vivo olarak senkronizasyonun modellenmesi eş zamanlı olarak matematiksel analizlerin de geliştirilmesi önem taşımaktadır. 
Teşekkür: Çalışmada kullanılan HT29 hücre hattının teminindeki yardımları için Dr. Belma Zengin'e (Bezmialem Vakıf Üniversitesi, Eczacılık Fakültesi, Farmasötik Kimya Anabilim Dalı) teşekkür ederiz. Çalışmanın matematiksel modellemelerdeki yönlendirmeleri için Sadullah Göncü’ye (Fatih Sultan Mehmet Vakif Üniversitesi, Mühendislik Fakültesi, İnşaat Mühendisliği Bölümü) teşekkür ederiz.

Çıkar Çatışması Beyanı: Yazarlar çıkar çatışması olmadığını bildirmişılerdir.

\section{Kaynaklar:}

Akashi, M., \& Takumi, T. (2005). The orphan nuclear receptor RORalpha regulates circadian transcription of the mammalian core-clock Bmal1. Nat Struct Mol Biol, 12(5), 441-448. doi:10.1038/nsmb925

Bairoch, A. (2018). The Cellosaurus, a CellLine Knowledge Resource. J Biomol Tech, 29(2), 25-38. doi:10.7171/jbt.18-2902-002

Balsalobre, A., Damiola, F., \& Schibler, U. (1998). A serum shock induces circadian gene expression in mammalian tissue culture cells. Cell, 93(6), 929-937.

Brody, H. (2015). Colorectal cancer. Nature, 521(7551), S1. doi:10.1038/521S1a

Cornelissen, G. (2014). Cosinor-based rhythmometry. Theor Biol Med Model, 11, 16. doi:10.1186/1742-4682-11-16

Dallmann, R., Okyar, A., \& Levi, F. (2016). Dosing-Time Makes the Poison: Circadian Regulation and Pharmacotherapy. Trends Mol Med, 22(5), 430-445. doi:10.1016/j.molmed.2016.03.004

Debruyne, J. P., Noton, E., Lambert, C. M., Maywood, E. S., Weaver, D. R., \& Reppert, S. M. (2006). A clock shock: mouse CLOCK is not required for circadian oscillator function. Neuron, 50(3), 465-477. doi:10.1016/j.neuron.2006.03.041

Fourier, J. (1822). Théorie Analytique de la Chaleur. Paris, France.
Izumo, M., Sato, T. R., Straume, M., \& Johnson, C. H. (2006). Quantitative analyses of circadian gene expression in mammalian cell cultures. PLoS Comput Biol, 2(10), e136. doi:10.1371/journal.pcbi.0020136

Katamune, C., Koyanagi, S., Hashikawa, K. I., Kusunose, N., Akamine, T., Matsunaga, N., \& Ohdo, S. (2018). Mutation of the gene encoding the circadian clock component PERIOD2 in oncogenic cells confers chemoresistance by up-regulating the Aldh3a1 gene. $J$ Biol Chem. doi:10.1074/jbc.RA118.004942

Lesicka, M., Jablonska, E., Wieczorek, E., Seroczynska, B., Siekierzycka, A., Skokowski, J., . . Reszka, E. (2018). Altered circadian genes expression in breast cancer tissue according to the clinical characteristics. PLoS One, 13(6), e0199622. doi:10.1371/journal.pone.0199622

Levi, F., Okyar, A., Dulong, S., Innominato, P. F., \& Clairambault, J. (2010). Circadian timing in cancer treatments. Аnnu Rev Pharmacol Toxicol, 50, 377-421. doi:10.1146/annurev.pharmtox.48.113006.09 4626

Marquardt, D. W. (1963). An Algorithm for Least-Squares Estimation of Nonlinear Parameters. Journal of the Society for Industrial and Applied Mathematics, 11(2), 431-441.

doi:https://doi.org/10.1137/0111030

Mazzoccoli, G., Vinciguerra, M., Papa, G., \& Piepoli, A. (2014). Circadian clock circuitry in colorectal cancer. World J Gastroenterol, 20(15), 4197-4207. doi:10.3748/wjg.v20.i15.4197

Minami, Y., Ode, K. L., \& Ueda, H. R. (2013). Mammalian circadian clock: the roles of transcriptional repression and delay. Handb Exp Pharmacol(217), 359-377. doi:10.1007/978-3-642-25950-0_15

Momma, T., Okayama, H., Saitou, M., Sugeno, H., Yoshimoto, N., Takebayashi, Y., . . . Takenoshita, S. (2017). Expression of circadian clock genes in human colorectal 
adenoma and carcinoma. Oncol Lett, 14(5), 5319-5325. doi:10.3892/ol.2017.6876

Mteyrek, A., Filipski, E., Guettier, C., Okyar, A., \& Levi, F. (2016). Clock gene Per2 as a controller of liver carcinogenesis. Oncotarget, $\quad 7(52), \quad 85832-85847$. doi:10.18632/oncotarget.11037

Nelson, W., Tong, Y. L., Lee, J. K., \& Halberg, F. (1979). Methods for cosinorrhythmometry. Chronobiologia, 6(4), 305323.

Ozturk, N., Ozturk, D., Kavakli, I. H., \& Okyar, A. (2017). Molecular Aspects of Circadian Pharmacology and Relevance for Cancer Chronotherapy. Int J Mol Sci, 18(10). doi:10.3390/ijms18102168

Özbayer, C. (2011). Circadian clock, cell cycle and cancer. Dicle Medical Journal / Dicle tip Dergisi, 38(4), 514-518. doi:10.5798/diclemedj.0921.2011.04.0080

Pardini, L., Kaeffer, B., Trubuil, A., Bourreille, A., \& Galmiche, J. P. (2005). Human intestinal circadian clock: expression of clock genes in colonocytes lining the crypt. Chronobiol Int, 22(6), 951-961. doi:10.1080/07420520500395011

Pilanci, K. N., Saglam, S., Okyar, A., Yucel, S., Pala-Kara, Z., Ordu, C., . . . KaytanSaglam, E. (2016). Chronomodulated oxaliplatin plus Capecitabine (XELOX) as a first line chemotherapy in metastatic colorectal cancer: A Phase II Brunch regimen study. Cancer Chemother Pharmacol, 78(1), 143-150. doi:10.1007/s00280-016-3067-x

Puram, R. V., Kowalczyk, M. S., de Boer, C. G., Schneider, R. K., Miller, P. G., McConkey, M., . . . Ebert, B. L. (2016). Core Circadian Clock Genes Regulate Leukemia Stem Cells in AML. Cell, 165(2), 303-316. doi:10.1016/j.cell.2016.03.015

Refinetti, R., Lissen, G. C., \& Halberg, F. (2007). Procedures for numerical analysis of circadian rhythms. Biol Rhythm Res, 38(4), 275-325. doi:10.1080/09291010600903692
Reszka, E., \& Zienolddiny, S. (2018). Epigenetic Basis of Circadian Rhythm Disruption in Cancer. Methods Mol Biol, 1856, 173-201. doi:10.1007/978-1-49398751-1_10

Sato, T. K., Panda, S., Miraglia, L. J., Reyes, T. M., Rudic, R. D., McNamara, P., .. . Hogenesch, J. B. (2004). A functional genomics strategy reveals Rora as a component of the mammalian circadian clock. Neuron, 43(4), 527-537. doi:10.1016/j.neuron.2004.07.018

Schibler, U. (2005). The daily rhythms of genes, cells and organs. Biological clocks and circadian timing in cells. EMBO Rep, 6 Spec No, S9-13. doi:10.1038/sj.embor.7400424

Schibler, U., Gotic, I., Saini, C., Gos, P., Curie, T., Emmenegger, Y., . . . Franken, P. (2015). Clock-Talk: Interactions between Central and Peripheral Circadian Oscillators in Mammals. Cold Spring Harb Symp Quant Biol, $\quad 80, \quad 223-232$. doi:10.1101/sqb.2015.80.027490

Siegel, R. L., Miller, K. D., Fedewa, S. A., Ahnen, D. J., Meester, R. G. S., Barzi, A., \& Jemal, A. (2017). Colorectal cancer statistics, 2017. CA Cancer J Clin, 67(3), 177-193. doi:10.3322/caac. 21395

Türkiye Kanser İstatistikleri. (2015).

Winter, S. L., Bosnoyan-Collins, L., Pinnaduwage, D., \& Andrulis, I. L. (2007). Expression of the circadian clock genes Per1 and Per2 in sporadic and familial breast tumors. Neoplasia, 9(10), 797-800.

Wood, P. A., Yang, X., \& Hrushesky, W. J. (2009). Clock genes and cancer. Integr Cancer Ther, 8(4), 303-308. doi:10.1177/1534735409355292

Yang, M. Y., Yang, W. C., Lin, P. M., Hsu, J. F., Hsiao, H. H., Liu, Y. C., . . . Lin, S. F. (2011). Altered expression of circadian clock genes in human chronic myeloid leukemia. $J$ Biol Rhythms, 26(2), 136-148. doi:10.1177/0748730410395527 
Zhang, J., Dong, X., Fujimoto, Y., \& Okamura, H. (2004). Molecular signals of Mammalian circadian clock. Kobe J Med Sci, 50(3-4), 101-109. 